\title{
Nitrogen fixation (acetylene reduction) in stony corals: evidence for coral-bacteria interactions
}

\author{
N. Shashar ${ }^{1,2, *}$, Y. Cohen ${ }^{3}$, Y. Loya ${ }^{2}$, N. Sar ${ }^{4}$ \\ ${ }^{1}$ The Interuniversity Institute of Eilat, H. Steinitz Marine Biology Laboratory, PO Box 469, Eilat 88 103, Israel \\ ${ }^{2}$ Tel Aviv University, Dept of Zoology, George S. Wise Faculty of Life Sciences, Tel Aviv 69978, Israel \\ ${ }^{3}$ The Hebrew University of Jerusalem, Division of Microbial and Molecular Ecology, Life Science Institute, \\ Jerusalem 91 904, Israel \\ ${ }^{4}$ Technion, Dept of Food Engineering and Biotechnology, Haifa 32 000, Israel
}

\begin{abstract}
Nitrogen fixation, as measured by acetylene reduction, has been detected to be associated with various hermatypic corals. Experiments were carried out on the massive coral Favia favus both in situ and in the laboratory. Nitrogen fixation activity was found to be light dependent and fully inhibited by $5 \times 10^{-6} \mathrm{M}$ DCMU [3-(3,4-dichlorophenyl)-1,1-dimethylurea]. Addition of glucose restored nitrogen fixation activity both in the dark and in the presence of DCMU. Removal of the coral tissue prevented acetylene reduction, while addition of glucose to the coral skeleton restored this activity. Bacteria isolated from the coral skeleton were found by dot blotting to contain the nif $\mathrm{H}$ gene. These results suggest that nitrogen-fixing bacteria found in the skeleton of corals benefit from organic carbon excreted by the coral tissue. The interaction between the nitrogen-fixing organisms and the coral may be of major importance for the nitrogen budget of the corals
\end{abstract}

KEY WORDS: Nitrogen fixation - Acetylene reduction · Coral F Favia favus

\section{INTRODUCTION}

Coral reefs predominate in oligotrophic oceans where nutrient availability limits primary productivity (Webb et al. 1975, D'Elia 1988). Along with concentration of nutrients from the open sea via predation on planktonic organisms (Erez 1990), prokaryotic atmospheric nitrogen assimilation/fixation is a primary source of combined nitrogen to the reef (Wiebe et al. 1975, D'Elia 1988, D'Elia \& Wiebe 1990).

Nitrogen fixation has been detected in a variety of locations within reefs (Hanson 1974, Mague \& HolmHansen 1975, Wilkinson \& Fay 1979, Wilkinson et al. 1984, 1985, Larkum 1988, Larkum et al. 1988, Capone et al. 1992), including the skeletons of living corals (Crossland \& Barnes 1976, Williams et al. 1987).

- Present address: Dept of Biological Sciences, University of Maryland, Baltimore County, Catonsville, Maryland 21228, USA
Corals are known to effectively absorb combined nitrogen from seawater (Burris 1983, D'Elia 1988, D'Elia \& Cook 1988) and thus are postulated to limit organic nitrogen accumulation within and around the coral skeleton. Support for this assumption can be found in Risk \& Muller's (1983) description of lower combined nitrogen concentrations, within coral skeletons, than anticipated by respiration rates and $\mathrm{PO}_{4}{ }^{3-}$ concentrations. Low combined nitrogen levels will favor the growth of nitrogen-fixing organisms.

Cyanobacteria were suggested to be a main nitrogen-fixing organism in reefs (Hanson 1974, Mague \& Holm-Hansen 1975, Wiebe et al. 1975); however, no direct evidence has shown that cyanobacteria are the dominant diazotrophs within living corals.

Direct associations or symbiosis, between nitrogenfixing microorganisms and several marine animals such as sea urchins (Guerinot \& Patriquin 1981), sponges (Wilkinson \& Fay 1979) and shipworms (Waterbury et al. 1983) have been documented. In this 
research we attempted to address the possible interactions between living corals and the nitrogen-fixing organisms associated with them.

\section{MATERIALS AND METHODS}

Whole coral colonies, 3 to $7.5 \mathrm{~cm}$ in diameter, were sampled at a water depth of 4 to $6 \mathrm{~m}$, from a coral reef off the H. Steinitz Marine Biology Laboratory in Eilat, Israel. Epiphytic macroalgae and all dead parts were carefully removed from the coral under water, immediately after sampling. Nine common coral species were examined for acetylene reduction activity (Table 1). For further detailed experiments the massive coral Favia favus was chosen, due to its abundance at this location.

Nitrogen fixation was estimated in situ and in the laboratory using the acetylene reduction method (Stewart et al. 1967, Hardy et al. 1968).

In situ incubations. Sealed glass incubation chambers, $1100 \mathrm{ml}$ in volume, equipped with nontoxic Vacutainer ${ }^{\circledR}$ syringe valves at the top and bottom, were used in a procedure following Williams et al. (1987). Each chamber was attached to a buoy and anchored to the reef so that it floated, lid facing down, at $5.0 \mathrm{~m}$ depth. Chambers were filled in the lab with a gas mixture of $70 \% \mathrm{Ar}, 20 \% \mathrm{O}_{2}$ and $10 \% \mathrm{C}_{2} \mathrm{H}_{2}$. While opening the lid and inserting samples, the gas mixture compressed and $450 \mathrm{ml}$ of seawater entered the jar. Duplicate gas phase samples were collected with freshly evacuated test tubes (Vacutainer ${ }^{\circledR}$ ). To compensate for a possible lag phase or diffusion limitations in situ and laboratory experiments were incubated for $60 \mathrm{~h}$. Experimental controls of Favia favus corals incubated without acetylene $\left(80 \% \mathrm{Ar}, 20 \% \mathrm{O}_{2}\right)$ to determine background $\mathrm{C}_{2} \mathrm{H}_{4}$ evolution (Patriquin 1978), and of seawater incubated with acetylene to check for free water or planktonic

Table 1. In situ acetylene reduction rates (nmol ethylene $\mathrm{cm}^{-2}$ $\mathrm{h}^{-1}$ ) associated with stony corals. Numbers in parentheses indicate number of replicates

\begin{tabular}{|lccc|}
\hline \multirow{2}{*}{ Coral } & \multicolumn{3}{c|}{ Acetylene reduction rate } \\
& Average & SD & Range \\
\hline Acropora sp. (3) & 8.70 & 7.3 & $1.73-18.81$ \\
Stylophora pistillata (2) & 6.43 & 2.4 & $4.00-8.88$ \\
Cyphastrea chalcidicum (3) & 6.23 & 0.3 & $5.93-6.57$ \\
Favia favus (4) & 4.39 & 1.9 & $2.53-7.42$ \\
Platygyra lamellina (3) & 4.39 & 5.9 & $0.0-12.78$ \\
Porites lobata (4) & 3.45 & 2.6 & $1.26-7.90$ \\
Pocillopora damicornis (3) & 0.61 & 0.4 & $0.0-1.00$ \\
Hydnophora contigntio (2) & 0.0 & & \\
Fungia fungites (3) & 0.0 & & \\
& & & \\
\hline
\end{tabular}

nitrogen-fixing activity, were incubated in situ and in the laboratory. Controls of seawater incubated with acetylene and $0.1 \%$ glucose were incubated in the laboratory. All controls were incubated for $72 \mathrm{~h}$. Light intensity within the experimental jars did not vary by more than $1 \%$ from the ambient light at $5 \mathrm{~m}$ (measured by a Li-Cor Li-1000 light meter with an underwater, cosine corrected, $2 \pi$ sensor).

Laboratory experiments. Laboratory incubation chambers were identical to those used in the underwater experiments. Corals were acclimated for $3 \mathrm{~h}$ (except in tissue-free experiments) in running seawater, at a dilution rate of $50 \%$ every $2 \mathrm{~min}$, within the experimental jars. Then, $600 \mathrm{ml}$ of water was removed, and the air replaced with a gas mixture of $70 \% \mathrm{Ar}$, $20 \% \mathrm{O}_{2}$ and $10 \% \mathrm{C}_{2} \mathrm{H}_{2}$. Incubations $(60 \mathrm{~h}$ for experimental settings, and $72 \mathrm{~h}$ for controls) were carried out at $23^{\circ} \mathrm{C}$. Illumination was provided by fluorescent lamps, at a light intensity of $200 \mu \mathrm{E} \mathrm{m}^{-2} \mathrm{~s}^{-1}$ within the incubation chambers. Corals were kept in continuous light, $50 \%$ dark-light cycles $(4,8$ or $12 \mathrm{~h}$ each cycle, e.g. 4 h light: 4 h dark, 8 h cycle), or in the dark.

To better define the contribution of the living coral (cnidarian and zooxanthellae) to the acetylene reduction process, the coral tissue was removed using a strong seawater jet (water-pik). Possible relationships between nitrogen fixation and photosynthesis were evaluated in experiments carried out in the dark and in the light, and in experiments in which a photosystem 2 inhibitor, DCMU [3-(3,4-dichlorophenyl)-1,1-dimethylurea, DuPont, Basel, Switzerland] was added, at a final concentration of $5 \times 10^{-6} \mathrm{M}$. In several experiments, glucose was added to the overlying seawater at final concentrations of 0.01 to $1 \%$.

Bacterial isolation. A freshly collected Favia favus coral was washed with sterile seawater and halved. Each half was imprinted onto agar plates of the following medium: nitrogen-free MN11 (Rippka 1988) and MN11 supplemented with $0.1 \%$ glucose. After $72 \mathrm{~h}$ at $25^{\circ} \mathrm{C}$ and in the light, the dominating colonies from each plate, originating from different parts of the coral skeleton, were isolated. Other bacterial strains used were Escherichia coli DH5 (Sambrook et al. 1989) and Klebsiella pneumoniae. Both strains were maintained on LB agar.

Analytical methods. Acetylene and ethylene concentrations were determined using a gas chromatograph (HP 5890) equipped with a J\&W $30 \mathrm{~m}$ long, semicapillary $(0.53 \mathrm{~mm})$ GS-Q column, and a FID detector. The sampling procedure (He as a carrier gas at a flow rate of $4 \mathrm{ml} \mathrm{min}{ }^{-1}$, injector temperature $200^{\circ} \mathrm{C}$, oven temperature $45^{\circ} \mathrm{C}$, detector temperature $250^{\circ} \mathrm{C}$ ) enabled separation of over $20 \mathrm{~s}$ between ethylene and acetylene peaks. Estimations of nitrogen fixation rates from ethylene evolution were based on the 
conservative ratio of $1: 4 \mathrm{~N}_{2}: \mathrm{C}_{2} \mathrm{H}_{4}$, assuming that $1 \mathrm{~mol}$ $\mathrm{N}_{2}$ would have been fixed for every $4 \mathrm{~mol} \mathrm{C}_{2} \mathrm{H}_{4}$. Although a $1: 3.45$ ratio has been commonly utilized in coral reef environments (after Larkum et al. 1988) it was recommended that the higher $1: 4$ ratio should be used when ${ }^{15} \mathrm{~N}$ calibration is not applied, in order to offset any nitrogenase-dependent $\mathrm{H}_{2}$ evolution that can occur in the presence of $\mathrm{N}_{2}$ but not in the presence of $\mathrm{C}_{2} \mathrm{H}_{2}$ (Patriquin \& McClung 1978, Taylor 1983).

In all cases, we could identify a lag phase of approximately $3 \mathrm{~h}$ in which ethylene evolution was not detected. After this preliminary phase, acetylene reduction rates were continuously linear. Long lag phases, occasionally exceeding $20 \mathrm{~h}$, have been previously reported (Patriquin 1978, Patriquin \& McClung 1978, Williams et al. 1987, Shieh \& Lin 1992) and were suggested to result from temporary inhibition of the nitrogenase by $\mathrm{O}_{2}$ (Patriquin 1978, Taylor 1983), and from the time required for diffusion of the acetylene through the liquid phase (Taylor 1983, Shieh \& Lin 1992), or into the coral skeleton. After this preliminary phase, ethylene formation maintained a constant (linear) rate, suggesting that the long incubations, though not essential, did not artificially enrich the nitrogenfixing bacterial community within the chambers.

Activity rate was calculated per total coral surface area, measured using the aluminum foil method (Porter et al. 1984). Branching corals were broken into fragments prior to surface measurements, to insure results of equivalent validity across species. Though this is a crude method, which may introduce its own variability to the results, total coral surface area is closely related to the tissue surface area, an important factor for interactions between coral and free-living microorganisms. Nevertheless, one must bear in mind that endolithic organisms have a much larger surface and volume available to them.

Ammonia concentrations, in all incubation chambers, were monitored using an E.M. Science Aquaquant $14428 \mathrm{kit}$, modified for a $0.5 \mu \mathrm{M}$ detection sensitivity limit. Ammonia concentrations did not change significantly from ambient levels in any of the chambers during the experiments.

Colony blot analysis of bacteria isolated from Favia favus. A $1.8 \mathrm{kbp}$ fragment containing part of the nif HDKY operon from Klebsiella pneumoniae was used as a probe. This fragment, which contains the entire nif $\mathrm{H}$ gene, part of the nif $\mathrm{D}$ gene and no vector DNA, was isolated from plasmid pBJ100 (Berman et al. 1985) using the restriction enzymes Eco-R1 and Bam-H1 (IBI, Oklahoma, USA). The purified fragment was radioactively labeled by the random oligonucleotide priming technique. Colony blotting was carried out after growing bacteria in their optimal medium, $M N-11$ glucose for new isolates, and LB for $K$. pneu- moniae and Escherichia coll. A large colony $(3$ to $4 \mathrm{~mm}$ in diameter) was suspended in $20 \mu \mathrm{l}$ of saline solution. A sample of 1 or $10 \mu l$ of the cell suspension was transferred to nitrocellulose paper (Schleicher and Schuell, Germany). The bacterial suspension was air dried, lysed on a filter, and then baked for $2 \mathrm{~h}$ at $80^{\circ} \mathrm{C}$. After baking, the filter was washed, prehybridized and hybridized with nif $\mathrm{H}$ probe. General methods (e.g. Colony Blot Analysis, fragment isolation) were carried out according to Sambrook et al. (1989).

\section{RESULTS}

Several species of hermatypic corals were examined for acetylene reduction activity in a series of in situ underwater experiments (Table 1). Seven of the 9 coral species examined showed significant acetylene reduction activity, ranging from $0.61 \pm 0.4 \mathrm{nmol}$ ethylene $\mathrm{cm}^{-2} \mathrm{~h}^{-1}$ in Pocillopora damicornis to $8.70 \pm$ $7.3 \mathrm{nmol}$ ethylene $\mathrm{cm}^{-2} \mathrm{~h}^{-1}$ in Acropora sp. The calculated average rate of coral nitrogen fixation was $3.85 \pm 4.4 \mathrm{nmol}$ ethylene $\mathrm{cm}^{-2} \mathrm{~h}^{-1}$, well within the range of activity measured previously on living and dead coral heads (Crossland \& Barnes 1976, Larkum 1988, Larkum et al. 1988). Therefore, we accept the in situ measured rates as representing the natural activity. There were large variations in activity rate between colonies and 1 colony of $P$. damicornis and 1 of Platygyra lamellina did not show any activity. This high variability may result from specific interactions between the corals and the nitrogen-fixing bacteria, yet to be studied.

Underwater and laboratory experiments carried out on the massive coral Favia favus are presented in Table 2. Corals exposed to natural light cycles for $60 \mathrm{~h}$ during underwater incubations at $5 \mathrm{~m}$ water depth exhibited an acetylene reduction rate of $4.39 \pm$ $1.9 \mathrm{nmol}$ ethylene $\mathrm{cm}^{-2} \mathrm{~h}^{-1}$ while no activity could be detected in dark incubations.

Acetylene reduction rates of Favia favus corals incubated in the laboratory in light and dark cycles were $4.6 \pm 1.9 \mathrm{nmol}$ ethylene $\mathrm{cm}^{-2} \mathrm{~h}^{-1}$, similar to those recorded in underwater incubations $(n=4,2$-tailed t-test, $\mathrm{p}=0.8899$ ). In continuous light incubation, higher activity rates of $6.0 \pm 2.5 \mathrm{nmol}$ ethylene $\mathrm{cm}^{-2}$ $\mathrm{h}^{-1}$ were recorded. No significant difference $\left(\mathrm{R}^{2}=\right.$ 0.3398 ) in acetylene reduction rates existed among corals incubated under artificial light cycles of 4,8 and $12 \mathrm{~h}$ for each stage. Oxygen is known to inhibit nitrogen fixation. However, acetylene reduction rates were not inhibited by the hypoxic conditions that usually develop within coral skeletons under illumination (Shashar \& Stambler 1992); nor were they affected by the number of shifts from light to darkness. Therefore, 
Table 2. Acetylene reduction rates ( $\mathrm{nmol}$ ethylene $\mathrm{cm}^{-2} \mathrm{~h}^{-1}$ ) associated with Favia favus corals. Numbers in parentheses inclicate number of replicates

\begin{tabular}{|c|c|c|c|}
\hline \multirow{2}{*}{ Incubation conditions } & \multicolumn{3}{|c|}{ Acetylene reduction rate } \\
\hline & Average & $\mathrm{SD}$ & Range \\
\hline \multicolumn{4}{|l|}{ In situ } \\
\hline \multicolumn{4}{|l|}{ Intact coral } \\
\hline Diurnal light cycle (4) & 4.39 & 1.9 & $2.53-7.42$ \\
\hline Dark (3) & 0 & & \\
\hline \multicolumn{4}{|l|}{ Laboratory } \\
\hline \multicolumn{4}{|l|}{ Intact coral } \\
\hline Light/dark cycle ${ }^{a}(4)$ & 4.6 & 1.9 & $2.6-7.2$ \\
\hline Light (5) & 6.0 & 2.5 & $3.4-8.5$ \\
\hline Dark (4) & 0 & & \\
\hline Dark: Glucose $0.1 \%(1)$ & 1.9 & & \\
\hline Light: DCMU (2) & 0 & & \\
\hline $\begin{aligned} \text { Light: } & \text { DCMU+ } \\
& \text { glucose } 0.1 \% \text { (2) }\end{aligned}$ & 58.5 & 49.0 & $9.6-107.4$ \\
\hline \multicolumn{4}{|l|}{ Coral skeleton } \\
\hline Light (2) & 0 & & \\
\hline Light: Glucose $0.01-1 \%(14)$ & 13.4 & 15.8 & $0.7-56.4$ \\
\hline
\end{tabular}

we conclude that the nitrogen-fixing agents possess defensive mechanisms against the inhibitory effect of oxygen.

The occurrence of acetylene reduction in the light and its absence in the dark suggests a possible contribution of photosynthesis to this process. Indeed, when colonies of Favia favus corals were incubated in the light in the presence of $5 \times 10^{-6} \mathrm{M} \mathrm{DCMU}$, no acetylene reduction could be detected.

DCMU-sensitive, oxygenic photosynthesis can be directly related to the acetylene reduction process if the latter is carried out by oxygenic photosynthetic microorganisms. On the other hand, it can be indirectly connected to the acetylene reduction process by supplying an organic carbon source to heterotrophic, nitrogen-fixing microorganisms. Corals incubated in the dark or in the light in the presence of $5 \times 10^{-6} \mathrm{M}$ DCMU, both with the addition of $0.1 \%$ glucose, exhibited significant rates of acetylene reduction (Table 2). However, the high variability in the results prevents further discussion beyond the existence of activity. These results suggest that heterotrophic bacteria, rather than oxygenic photosynthetic microorganisms, contribute to this process. When a Favia favus coral was incubated in the light in the presence of $5 \times 10^{-6} \mathrm{M}$ DCMU, no acetylene reduction could be detected even after $89 \mathrm{~h}$. When $0.1 \%$ glucose was then added, acetylene reduction commenced at a maximal rate of $146 \mathrm{nmol}$ ethylene $\mathrm{cm}^{-2} \mathrm{~h}^{-1}$ and persisted for the following $50 \mathrm{~h}$.
An attempt was made to localize the nitrogen-fixing bacteria and the photosynthetic organisms that provide the carbon source. The coral tissue was separated from the skeleton, and the latter was examined for acetylene reduction. No acetylene reduction activity could be detected when coral skeletons were incubated in the light. However, the addition of glucose restored this activity (Table 2 ) at a similar rate to that of the intact coral incubated with DCMU and glucose (2-tailed $t$-test, $p=0.2259$ ). Therefore, we conclude that the natural energy source for the nitrogen fixation processes within the skeletons lies in the tissue of the coral itself.

In experiments of tissue-free coral heads incubated at glucose concentrations of 0.01 to $1.0 \%$, acetylene reduction rates were not correlated to sugar concentrations $\left(n=14, R^{2}=0.1216\right)$. Therefore, even the addition of $0.01 \%$ glucose may have saturated the demands of the acetylene reduction process, yet higher glucose concentrations do not have an inhibitory effect on the activity. In 4 out of the 14 jars, the addition of glucose caused the aqueous phase to turn turbid, possibly due to intense bacterial growth. However, activity rates did not vary from incubations which remained clear throughout the experiment.

In $72 \mathrm{~h}$ control incubations, acetylene reduction was not detected in chambers containing only seawater with or without glucose, nor could ethylene formation be found in corals incubated without acetylene.

In the bacterial isolation experiments, in which agas plates were inoculated by imprinting of halved corals, the plates were covered $24 \mathrm{~h}$ after inoculation with numerous colonies of agar-degrading bacteria. From each of the coral imprints, 2 of the agar-degrading colonies that also looked the most abundant type of colony on MN11-glucose plates were isolated for further studies. Colonies removed from agar plates failed to reduce acetylene under aerobic and anaerobic conditions

Colonies of the new isolates (strains N4, N5, N6 and N7) as well as positive controls (Klebsiella pneumoniae) and negative controls (Escherichia coli and herring sperm DNA) were hybridized with fragments of nif $\mathrm{H}$ gene from $K$. pneumoniae (Fig. 1). Two coral isolates (N4 and N5) gave signals comparable to those obtained with $K$. pneumoniae. The negative controls, as well as strains N6 and N7, gave no signals.

\section{DISCUSSION}

Acetylene reduction activity rates measured in the underwater experiments can be translated into an approximate nitrogen fixation rate of $0.96 \pm 1.1 \mathrm{nmol}$ $\mathrm{N}_{2} \mathrm{~cm}^{-2} \mathrm{~h}^{-1}$. This rate is within the range of nitrogen 
Fig. 1. Colony blot analysis of bacteria isolated from Favia favus coral probed with Klebsiella pneumoniae nif $\mathrm{H}$ and exposed to $\mathrm{X}$-ray film for $24 \mathrm{~h}$. The strains and the volumes of the bacterial suspension blotted are as follows: a1 (line a, column 1): $K$. pneumoniae, $10 \mu \mathrm{l}$; 2: Escherichia coli, $10 \mu l_{;}$a3: herring sperm DNA, $10 \mu l_{i}$ a5: N4, $1 \mu l_{i}$ b5: N4, $10 \mu l_{\text {; }}$ a6: N5, $1 \mu 1$; b6: N5, $10 \mu l ; a 4: N 6$, $10 \mu l_{i}$ b4: N6, $1 \mu l_{i}$ b1: N7, $10 \mu l_{i}$ b2: N7, $1 \mu l$

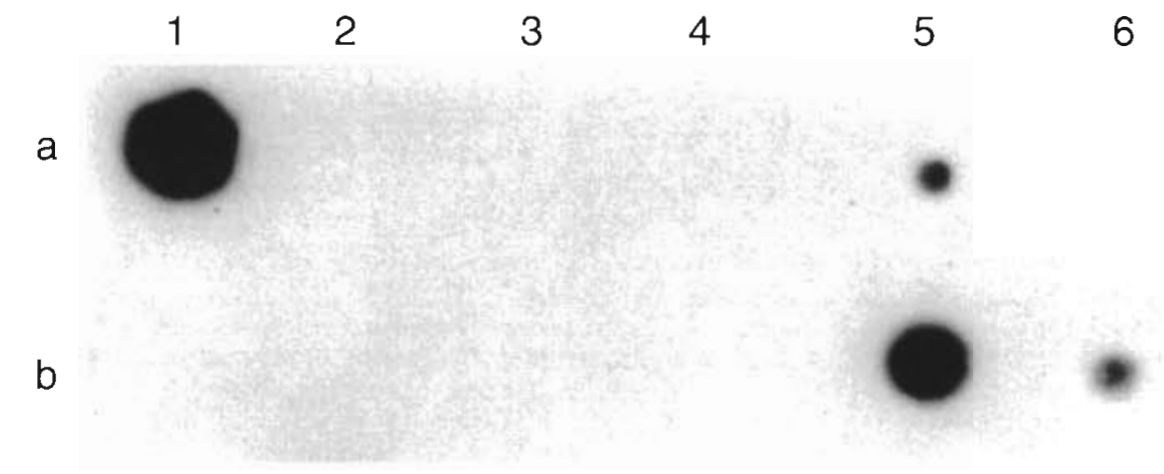

fixation detected on dead coral heads as well as other substrates in reef environment (Larkum et al. 1988). Our measurements are also in agreement with acetylene reduction rates found by Crossland \& Barnes (1976) in living massive Goniastrea australensis corals.

Photosynthesis seems to be essential for nitrogen fixation in stony corals, as acetylene reduction could not be detected in the darkness nor when DCMU was added. Glucose addition restored this activity in both cases, suggesting that organic compounds are supplied to the nitrogen fixers. When taking into consideration that nitrogen fixation consumes a high amount of energy (Falkowski 1983), the need for an energy source is not surprising. The exact amount of energy required cannot be determined, since we did not detect the limiting quantity of glucose needed for nitrogen fixation.

A key biological question is whether the nitrogen fixers themselves or the corals symbiotic algae, the zooxanthellae, are supplying the energy for nitrogen fixation. Removal of the coral tissue prevented acetylene reduction, and addition of glucose to the tissue-free coral skeletons restored this activity. These results suggest that the energy source for this nitrogen-fixing activity is not within the skeleton, but rather within the living coral (animal and algae) itself. Corals are known to excrete high quantities of organic carbon in various forms (Crossland 1987, Meikle et al. 1988). Additionally, corals constantly lay an organic matrix into their skeleton. However, obligatory excretion into the skeleton or the exact carbon compounds excreted by the coral and consumed by the bacteria are yet to be identified.

Previous researchers interpreted similar results of light requirements for nitrogen fixation in stony corals as evidence that cyanobacteria are the likely nitrogen fixers (Crossland \& Barnes 1976, Williams et al. 1987). Our results imply that endolithic heterotrophic bacteria, which receive energy from the living coral, are important dinitrogen-reducing agents. This interpretation does not contradict the basic results of Crossland \&
Barnes (1976) and Williams et al. (1987), but rather suggests a different interpretation of their findings.

We suggest that the nif $\mathrm{H}$-containing, agar-degrading bacteria inside the coral skeleton, are possible candidates for carrying out nitrogen fixation activity associated with Favia favus. Agarase activity of marine nitrogen-fixing bacteria has been previously reported by Shieh et al. (1988). When regarding the dot blot hybridization results one must bear in mind that this method may generate false positive results. Therefore our results present only a first indication that the N-4 and N-5 strains are indeed the nitrogen-fixing agents. Many bacteria carry out the nitrogen-fixation reaction only under very strict conditions (Postgate 1982). Most slow-growing Rhizobium sp. will fix nitrogen only in the symbiotic form. Additionally, the small compartments within the coral skeleton may enable the microorganisms to inhabit chemically unique microzones. Thus, it is not surprising that pure cultures of strains $\mathrm{N} 4$ and $\mathrm{N} 5$ did not reduce acetylene under the conditions tested. For exact identification of the coral's associated diazotroph, further bacterial isolation and cloning along with the use of specific antibodies are required. Some of these experiments are currently under way.

We suggest that, in the microhabitat of the coral head, the living coral excretes organic photosynthates into the coralline skeleton. These carbon substances are utilized by endolithic, nitrogen-fixing bacteria as the main energy source for the dinitrogen reducing process. The nitrogen-fixing bacteria secrete or degenerated into nitrogen-containing compounds within the coral skeleton. Ferrer \& Szmant (1988) reported excretion of $\mathrm{NH}_{4}^{+}$by the endolithic community of coral skeletons at rates of 0.8 to $1.4 \mathrm{nmol} \mathrm{NH}_{4}{ }^{+} \mathrm{cm}^{-2} \mathrm{~h}^{-1}$, similar to the $\mathrm{N}_{2}$ fixation rate. It is reasonable to assume that these nitrogen compounds are available as a nitrogen source to the living coral (Ferrer \& Szmant 1988).

Corals live in a nutrient-poor environment. Having a close association with nitrogen-fixing organisms may be to their great advantage. 
Acknowledgements. We thank Dr R. Ideses for her assistance in developing the acetylene reduction technique, and $\mathrm{A}$. Lut$\mathrm{fac}$ and $\mathrm{T}$ Feldstein for their invaluable help in both laboratory and underwater work. We are grateful to Dr A. Zamir for kindly providing the Klebsiella pneumoniae strain and the pBJ100 plasmid. This research was supported by a fellowship from the Tel Aviv University, a grant of the Israel Ministry of Science and Technology and GSF, Munich, Germany, and the Moshe Shilo Center for Marine Biogeochemistry. N.Sh. was partly supported by the H. Steinitz Foundation and the Wolt Foundation. N.Sa. was supported by a grant from the Hebrew University.

\section{LITERATURE CITED}

Berman, J., Gershoni, J. M., Zamir, A. (1985). Expression of nitrogen fixation genes in foreign hosts: assembly of nitrogenase Fe protein to E. coli and yeast. J. Biol. Chem. 260: $5240-5243$

Burris, R. H. (1983). Uptake and assimilation of ${ }^{15} \mathrm{NH}_{4}{ }^{+}$by a variety of corals. Mar. Biol. 75: 151-155

Capone, D. G., Dunham, S. E, Horngan, S. G., Duguay, L. E. (1992). Microbial nitrogen transformation in unconsolidated coral reef sediments. Mar. Ecol. Prog. Ser. 80: 75-88

Crossland, C. J. (1987). In situ release of mucus and DOClipid from the coral Acropora variabilis and Stylophora pistillata in different light regimes. Coral Reefs 6: 35-42

Crossland, C. J., Barnes, D. J. (1976). Acetylene reduction by coral skeletons. Limnol. Oceanogr. 21: 153-156

D'Elia, C. F. (1988). The cycling of essential elements in coral reefs. In: Pomeroy, L. R., Alberts, J. J. (eds.) Concepts of ecosystem ecology. Springer-Verlag, New York, p $195-230$

D'Elia, C. F., Cook, C. B. (1988). Methylamine uptake by zooxanthellae-invertebrate symbioses: insights into host ammonium environment and nutrition. Limnol. Oceanogr. 33(5): 1153-1165

D'Elia, C. F., Wiebe, W. J. (1990). Biogeochemical nutrient cycles in coral reef ecosystems. In: Dubinsky, Z. (ed.) Coral reefs. Elsevier, Amsterdam, p. 49-74

Erez, J. (1990). On the importance of food sources in the coral-reef ecosystems. In: Dubinsky, Z. (ed.) Coral reefs. Elsevier, Amsterdam, p. 411-418

Falkowski, P. G. (1.983). Enzymology of nitrogen assimilation. In: Carpenter, E. J. Capone, D. G. (eds.) Nitrogen in the marine environment. Academic Press, New York, p. $839-868$

Ferrer, L. M., Szmant, A. M. (1988). Nutrient regeneration by the endolithic community in coral skeletons. Proc. 6th int. coral Reef Symp. 3: 1-4

Guerinot, M. L., Patriquin, D. G. (1981). The association of $\mathrm{N}_{2}$ fixing bacteria with sea urchins. Mar. Biol. 62: 197-207

Hanson, R. B. (1974). Biological nitrogen fixation in a subtropical eutrophic estuary of Kaneohe Bay, Oahu, Hawaii. Ph.D. dissertation, University of Hawaii, Honolulu

Hardy, R. W. F., Holsten, R. D., Jackson, E. K., Burns, R. C. (1968). The acetylene-ethylene assay for $\mathrm{N}_{2}$ fixation: laboratory and field evaluation. Plant. Physiol. 43: 1185-1207

Larkum, A. W. D. (1988). High rates of nitrogen fixation on coral skeletons after predation by the crown of thorns starfish Acanthaster planci. Mar. Biol. 97: 503-506

Larkum, A. W. D., Kennedy, I. R., Muller, W. J. (1988). Nitrogen fixation on a coral reef. Mar. Biol 98: 1.43-155

Mague, T H., Holm-Hansen, O. (1975). Nitrogen fixation on a coral reef. Phycologia 14(2): 87-92

Meikle, P., Richards, G. N., Yellowlees, D. (1988). Structural investigation on the mucus from six species of coral. Mar. Biol. 99: 187-193

Patriquin, D. G. (1978). Factors affecting nitrogenase activity (acetylene-reducing activity) associated with excised roots of the emergent halophyte Spartina alterniflora Loisel. Aquat. Bot. 4: 193-210

Patriquin. D. G., McClung, C. R. (1978). Nitrogen accretion and the nature and possible significance of $\mathrm{N}_{2}$ fixation (acetylene reduction) in a Nova Scotian Spartina alterniflora stand. Mar. Biol. 47: 227-242

Porter, J. W., Muscatine, L., Dubinsky, Z., Falkowski, P. G. (1984). Primary production and photoadaptation in the light and shade adapted colonies of the symbiotic coral Stylophora pistillata. Proc. R. Soc. Lond. B 222: 161-180

Postgate, J. (1982). The fundamentals of nitrogen fixation. Cambridge Univ. Press, Cambridge

Rippka, R., (1988). Recognition and identification of cyanobacteria. Meth. Enzymol. 167: 1-27

Risk, M., Muller, H. R. (1983). Porewater in coral heads: evidence for nutrient regeneration. Limnol. Oceanogr. 28(5): $1004-1008$

Sambrook, J., Fritch, E. F., Maniatis, T (1989). Molecular cloning: a laboratory manual. Cold Spring Harbor Laboratory, Cold Spring Harbor, NY

Shashar, N., Stambler, N. (1992). Endolithic algae within corals - life at an extreme environment. J. exp. mar. Biol. Ecol. 163: 277-286

Shieh, W. Y., Simidu, U., Maruyama, Y (1988). Nitrogen fixation by marine agar-degrading bacteria. J. gen. Microbiol. 134: $1821-1825$

Shieh, W. Y., Lin, Y M. (1992). Nitrogen fixation (acetylene reduction) associated with the zoanthid Palythoa tuberculosa Esper. J. exp. mar. Biol. Ecol. 153: 31-41

Stewart, W. D. P., Fitzgerald, G. P., Burris, R. H. (1967). In situ studies on $\mathrm{N}_{2}$ fixation using the acetylene reduction technique. Proc natn. Acad. Sci. U.S.A. 58: 2017-2078

Taylor, B. R. (1983). Assays of microbial nitrogen transformation. In: Carpenter, E. J., Capon, D. G. (eds.) Nitrogen in the marine environment. Academic Press, New York, p. $809-838$

Waterbury, J. B., Calloway, C. B., Turner, R. D. (1983). A cellulolytic nitrogen-fixing bacterium cultured from the gland of Deshayes in shipworms (Bivalvia: Teredinidae). Science 221: 1401-1403

Webb, K. L., DuPaul, W. D., Wiebe, W., Sottile, W., Johannes, R. E. (1975). Enewetak (Eniwetok) Atoll: aspects of the nitrogen cycle on a coral reef. Limnol. Oceanogr. 20(2): $198-21.0$

Wiebe, W. J., Johannes, R. E., Webb, K. L. (1975). Nitrogen fixation in a coral reef community. Science 188: 257-259

Wilkinson, C. R., Fay, P. (1979). Nitrogen fixation in coral reef sponges with symbiotic cyanobacteria. Nature 279: $527-529$

Wilkunson, C. R., Sammarco, P. W. Trott, L. A. (1985). Seasonal and fish grazing effects on rates of nitrogen fixation on a coral reef. Proc. 5th int. coral Reef Congr. 4: 61-65

Wilkinson, C. R., Williams, D. McB., Sammarco, P. W., Hogg, R. W. Trott, L. A. (1984). Rates of nitrogen fixation across the continental shelf of the central Great Barrier Reef. Mar. Biol. 80: 255-262

Williams, W. M., Viner, A. B., Broughton, W. J. (1987). Nitrogen fixation (acetylene reduction) associated with the living coral Acropora variabilis. Mar. Biol 94: 531-535 